\title{
D02 ハイブリッド再生器を搭載したスターリング命凍機の動作特性に関する研究
}

\section{Study of Performance Characteristics on a Stirling Refrigerator with the Hybrid - Regenerator}

\author{
○学 前田 匡雅（都立大） 学 夏井 博行（都立大） \\ 正 太田 正廣（都立大） 正 大高 敏男（都立高専）
}

\author{
Tadamasa Maeda , Tokyo Metropolitan University , 1-1, Minami-osawa , Hachioji-shi , Tokyo \\ Hiroyuki Natsui , Tokyo Metropolitan University \\ Masahiro Ota , Tokyo Metropolitan University \\ Toshio Otaka , Tokyo Metropolitan College of Technology
}

\begin{abstract}
This paper describes some performance characteristics shown by the $\mathrm{P}-\mathrm{V}$ analysis on a stirling refrigerator with a hybrid regenerator made of copper matrixes and nylon ones for the less flow loss by changing the way to mix on hybrid matrixes.

In order to perform the efficiency of compact stirling refrigerators with a regenerator in the displacer well, it is effective to lighten the weight of regenerators and reduce motor input. For this reasons, we proposed using the hybrid regenerator. However, the nylon matrixes have larger flow loss than that of copper matrixes. Therefore the ratio of copper matrixes and nylon ones and the way to mix are important to improve the COP.
\end{abstract}

Key Words : Stirling refrigerator, Regenerator, Matrix, Nylon, Hybrid matrix , COP

\section{1. 緒論}

スターリング冷凍機はフロン系冷媒を必要としないので 自然環境に与える負荷が軽く, 理論効率がカルノ一効率と等 しいため, 地球に優しい冷凍システムということができる. しかし現状では家庭用冷凍機など常温レベルの分野に応用 されておらず, 家庭用として実用化するためには効率を上げ ることが必須課題である. また再生器はスターリングサイク ル機器において効率を高める重要な要素であり, この再生器 の性能の良否によってスターリング冷凍機の効率は大きく 左右される.このため本研究室では再生器に関して研究を重 ねてきた. すなわち, 再生器マトリクスにナイロンマトリク スと銅マトリクスを混合したハイブリッドマトリクス（以下 ハイブリッドマトリクスと呼ぶ) を用いることを提案してき た (1). 再生器マトリクスには金属マトリクスが多く用いられ てきたが, コンパクト化のため往復運動部分に再生器を構築 したディスプレーサ型スターリング冷凍機において, 銅より 軽いナイロンを混合しハイブリッド化することで機械損失 の低減を実現し, 冷凍機の消費電力を最大 $25 \%$ 低減できるこ とが明らかになった (1). またナイロンマトリクスを再生器マ トリクスとした場合, 同一機で銅マトリクスを使用した場合 の $80 \%$ 程度の冷凍能力を持つことが明らかになつた (1). しか しナイロンマトリクスを用いることで作動流体が再生器内 を通過する際に発生する流動損失が大きくなり，効率が低下 する問題がある(2). 以上のことから, ハイブリッドマトリク スの混合率と混合方法が効率を大きく左右することがわか っている.

本紙では, ハイブリッドマトリクスの混合方法を変えるこ とによる図示能力の違いを検討することを目的に, ハイブリ ッド再生器を搭載した円筒力ム型スターリング冷凍機（以下 2 号原型機と呼ぶ）における P-V 解析を行い, 各混合方法に おけるハイブリッド再生器を搭載したスターリング冷凍機 の動作特性を把握したので報告する.

\section{2-1. マトリクス}

$$
\text { 2.ハイブリッドマトリクス }
$$

マトリクスはFig. 1 に示すように, 銅およびナイロン瀻維 を直径 $50 \mathrm{~mm}$ の円形に切断し使用した. また参考として Table.1にナイロンと銅の物性值を示す.これよりナイロン マトリクスは銅マトリクスと比較して比重は約 $1 / 8$, 比熱は 約 5 倍, 開口比は約 1.3 倍となっている,
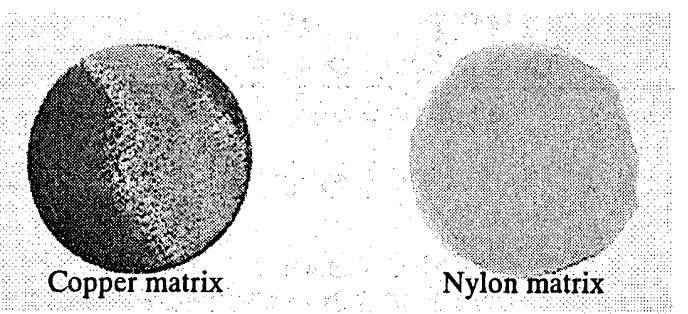

Fig.1 Matrix

Table.1 Properties of Copper and Nylon

\begin{tabular}{l|c|c}
\hline \multicolumn{1}{c|}{ Properties } & Copper & Nylon \\
\hline $\begin{array}{l}\text { Thermal conductivity } \\
{[\mathrm{W} / \mathrm{m} \cdot \mathrm{K}]}\end{array}$ & 400.0 & 0.882 \\
\hline $\begin{array}{l}\text { Density } \\
{\left[\mathrm{kg} / \mathrm{m}^{2}\right]}\end{array}$ & 8800.0 & 1130.0 \\
$\begin{array}{l}\text { Specific heat capacity } \\
{\left[\mathrm{J} / \mathrm{m}^{3} \cdot \mathrm{K}\right]}\end{array}$ & 400.0 & 1930.0 \\
\hline Open area ratio & 0.363 & 0.473 \\
\hline
\end{tabular}

\section{2-2.ハイブリッド混合率}

ハイブリッドマトリクスの混合率（以下混合率と呼ぶ）を $\varepsilon[\%]$ とし, 式(1)のように積載枚数で定義する.ここでは全 マトリクスの枚数は設計值である 200 枚を用いる. また, Table. 2 に両マトリクスが同じ圧力損失を持つときの重量と ディスプレーサの重量を示す.これによりナイロンマトリク ス $100 \%$ 充填時のディスプレーサ重量は, 銅マトリクス $100 \%$ 充填時のディスプレーサ重量における 0.6 倍程度であること がわかる.なお, 銅マトリクス $100 \%$ とナイロンマトリクス 100\%での評価はこの值を用いている.

$$
\begin{gathered}
\text { 混合率 } \varepsilon[\%]=\frac{\text { 銅マトリクスの枚数 }}{\text { 全マトリクスの枚数 }} \times 100 \\
(\varepsilon=0 \% \text { とき銅マトリクス } 100 \% \text { 充填 })
\end{gathered}
$$

Table.2 Matrix weights at $100 \%$ filling and displacer weights

\begin{tabular}{c|c}
\hline Type & Weights [g] \\
\hline Cu matrix $100 \%$ & 244.3 \\
\hline Nylon matrix $100 \%$ & 51.6 \\
\hline Displacer & 240.3 \\
\hline
\end{tabular}




\section{2-3. 実験条件}

本実験では混合率 $30 \%$ のハブリッドマトリクズを使用す る. 作動流体であるへリウムの封入ガス圧力を $300 \mathrm{kPa}$ ，モー 夕の運転周波数を $8,10,12,14 \mathrm{~Hz}$ とする. また混合方法によ る動作特性の違いを定量的に検討するため, Fig. 2 のように 分類する ${ }^{(3)}$.

Type 1：銅マトリクスを再生器の圧縮側に配置 Type 2：銅マトリクスを再生器の膨張側に配置 Type 3 : 銅マトリクスを再生器の中心に配置

Type 4 : 銅マトリクスとナイロンマトリクスを再生器全体 に均一に配置

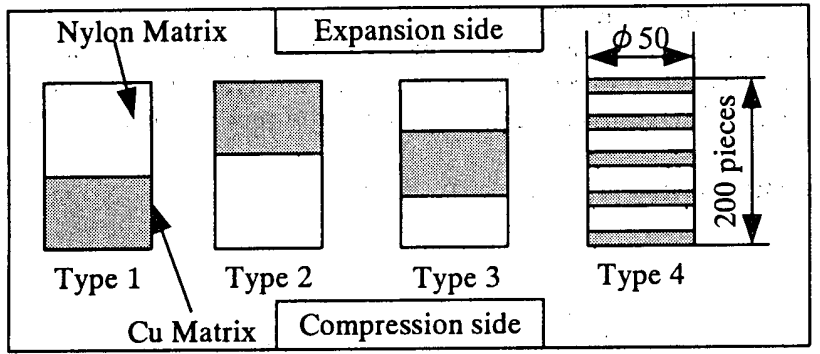

Fig.2 Types of Hybrid Matrix

\section{3. 実験装置}

2 号原型機の設計仕様をTable 3, 4 に,概略図をFig. 3 に示 す. また, 駆動機構部に円筒力ムを採用した実験機の特長を 以下に記す。

1. 部品点数が少ないため構造がシンプルである.

2. ピストン, カム, モ一タなどを同一直線上に配置できる ので小型化が図れ，潤滑経路の構成が容易である.

機械要素の潤滑, 冷却ならびに圧縮部の密封作用をする流体 として冷凍機油（ $\alpha$ オレライン系潤滑油）を使用した. 実験 機底部に設けられたオイルパンに貯留された潤滑油は，モー 夕駆動軸に内蔵した油ポンプにより軸中心部を通り副軸受 け, 円筒力ム, 主軸受け, カムフォロワに給油する. ただし, 圧縮ピストン, ディスプレーサなど動作空間には, 直接的に は給油を行わない，各摺動部に供給された潤滑油は，重力に よる自然滴下により再びオイルパンに戻る.このため, 実験 機の構成としては, 上部から順にシリンダ部（ディスプレー サ, 再生器及び圧縮ピストン), 駆動機構部, モ一夕などを 同二軸線上に配置されている. また，モ一夕は実験機本体内 部に設置されているため, 内部を循環する潤滑油によって冷 却される.

Table.3 Design specifications of cylindrical cam type refrigerator

\begin{tabular}{l|l}
\hline \hline Basic form & Displacer type \\
\hline Driving system & Cylindrical cam mechanism \\
\hline Working fluid & Helium \\
\hline Cooling capacity & $100 \mathrm{~W}$ \\
\hline Cold side temperature & $233 \mathrm{~K}$ \\
\hline Warm side temperature & $313 \mathrm{~K}$ \\
\hline Mean pressure & $700 \mathrm{kPa}$ \\
\hline Operation speed & $16.6 \mathrm{~Hz}$ \\
\hline Expansion swept volume & $56.5 \mathrm{~cm}^{3}$ \\
\hline Compression swept volume & $56.5 \mathrm{~cm}^{3}$ \\
\hline Total dead volume & $97.99 \mathrm{~cm}^{3}$ \\
\hline
\end{tabular}

Table4. Break down in the total dead volume

\begin{tabular}{l|l}
\hline Clearance in an expansion space & $10.55 \mathrm{~cm}^{3}$ \\
\hline Path between an expansion space and a regenerator & $2.16 \mathrm{~cm}^{3}$ \\
\hline Regenerator & $71.41 \mathrm{~cm}^{3}$ \\
\hline Path between a regenerator and a warm side heat exchanger & $3.74 \mathrm{~cm}^{3}$ \\
\hline Warm side heat exchanger & $2.65 \mathrm{~cm}^{3}$ \\
\hline Filling pipe for working fluid & $0.35 \mathrm{~cm}^{3}$ \\
\hline Path between a warm side exchanger and a compression space & $1.16 \mathrm{~cm}^{3}$ \\
\hline Clearace in a compression space & $5.97 \mathrm{~cm}^{3}$ \\
\hline
\end{tabular}

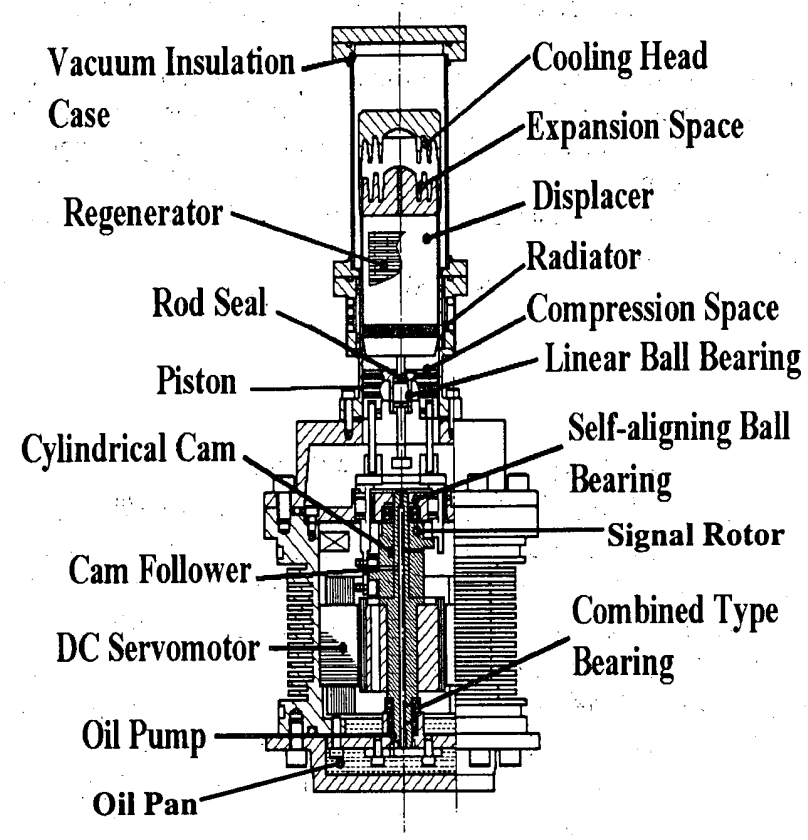

Fig .3 Schematic view of a cylindrical cam type Stirling refrigerator

\section{P-V 解析}

Fig. 2 に示した各混合方法におけるハイブリッド再生器を 搭載したスターリング冷凍機の動作特性を比較, 検討するた め図示能力を計算する.このため 2 号原型機の円筒力ム上部 に上死点信号用の凹部と 30 度ごとに凹部が刻まれたシグナ ルロシタを取り付け, クランク角度を測定する. これをギャ ップセンサによって検出し，検出されたクランク角度での膨 張空間・圧縮空間の圧力をセンサで測定し, 圧カアンプに送 る.このように検出されたクランク角度信号亡圧カアンプの 出力は共に FFT アナライザに送られ，PC 上で記録される. 圧 カアンプの出力から圧力への変換, クランク角度から動作空 間容積への換算は PC 上で換算式を用いて行なわれる．その 記録された換算データから P-V 線図を作成し, 図示冷凍能力, 図示圧縮仕事, 図示仕事, 図示 COP を計算する.

\section{5. 解析結果}

Fig. 2 に示した混合率 $30 \%$ の 4 種類のハイブリッド再生器 を使用した 2 号原型機の P-V 線図を Fig. 4, 5, 6, 7 に示す. Fig. 4, 6 は圧縮空間, Fig5, 7 は膨張空間のものであり, Fig. 4, 5 は運転周波数 8Hz, Fig, 6, 7 は $14 \mathrm{~Hz}$ のものである. いずれも縌軸である圧力は, 封入圧力の比として無次元圧力 として示した. 


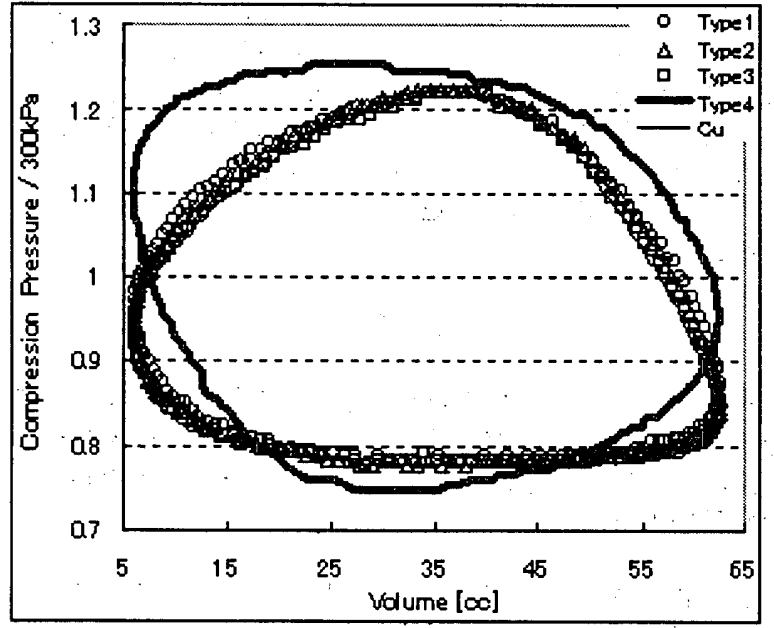

Fig. 4 P-V diagram of the compression side at motor operation Speed $8 \mathrm{~Hz}$

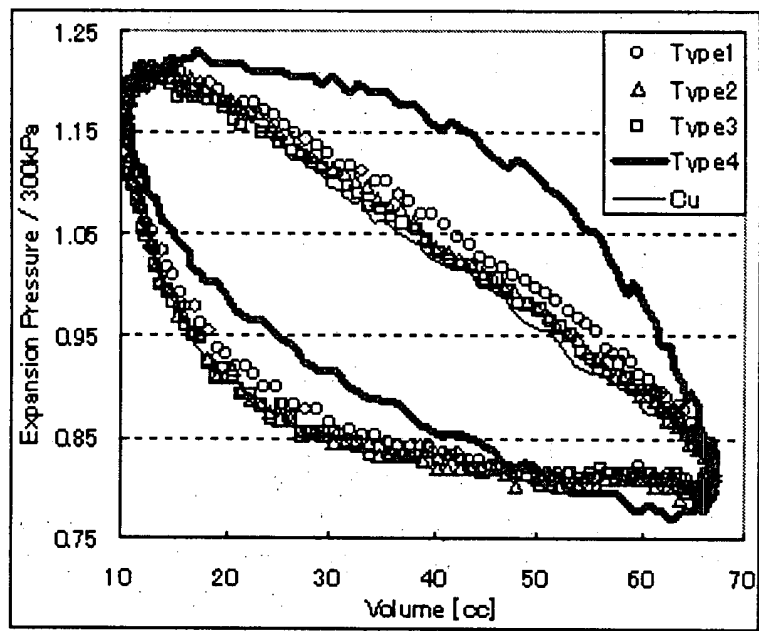

Fig. $5 \cdot P-V$ diagram of the Expansion side at motor operation speed $8 \mathrm{~Hz}$

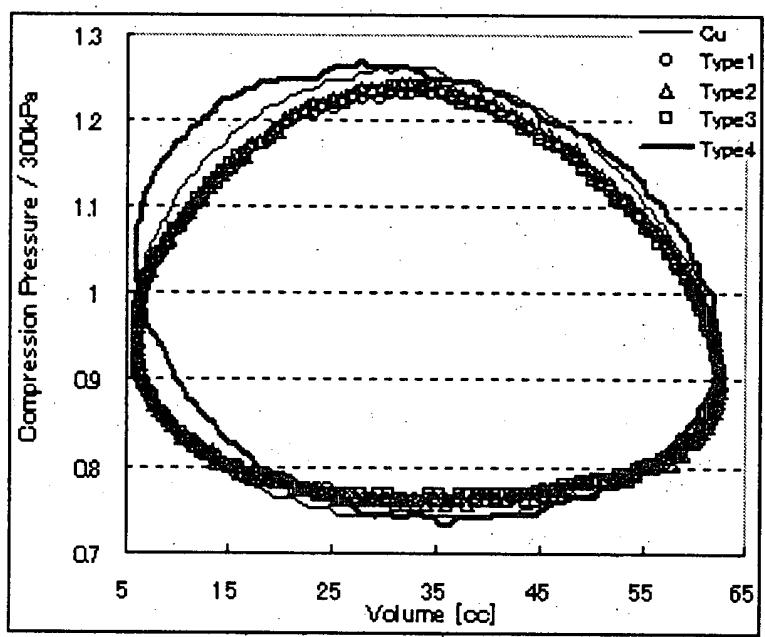

Fig. 6 P-V diagram of the compression side at motor operation speed $14 \mathrm{~Hz}$

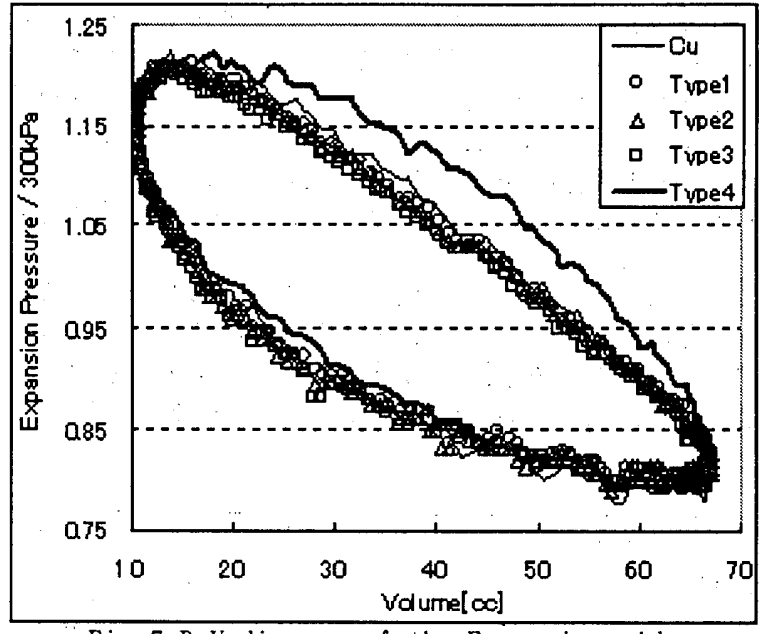

Fig. 7 P-V diagram of the Expansion side at motor operation speed $14 \mathrm{~Hz}$

Fig4, 5 より, Type1 のハイブリッド再生器を搭載すると, 銅のみを用いた再生器を搭載した場合と比べ $P-V$ 線図で囲ま れる領域が若干大きくなっていることがわかる. 特に高圧側 で圧力損失が小さいことがわかる. 逆に Type2 では低圧側で 圧力損失が小さいことがわかる.また Type3 では銅のみを用 いた再生器を用いた場合とほぼ変わらなかった。これは圧力 波によりナイロンマトリクスが変形し圧力損失を増大させ ているためで, 銅マトリクスを圧縮空間や膨張空間に混合す ることによりわずかであるが, この圧力損失の増加を低減可 能であることがわかる.

また Type4 のハイブリッド再生器を搭載すると, 他の再生 器を搭載するより $\mathrm{P}-\mathrm{V}$ 線図で囲まれる面積が大きいことが わかる.これは銅マトリクスによってナイロンマトリクスの 変形による圧力損失が抑制され，さらに開口比が大きいナイ ロンマトリクスの影響を受けて圧力損失が大幅に低減され たからであると考えられる.

Fig6, 7 より運転周波数が増大すると, Type4 の再生器を搭 載した場合の $\mathrm{P}-\mathrm{V}$ 線図は銅のみの再生器を搭載した場合に近 づいてくることがわかる.これは運転周波数が増大しナイロ ンマトリクスの変形による圧力損失が増加したため挙動が 近づいたと考えられる。

次に図示仕事と運転周波数の関係を Fig. 8 に示す.これは 銅マトリクスのみ使用した再生器を搭載した冷凍機と比較 するため, 縦軸は実験から得られたハイブリッド再生器を搭 載した冷凍機の図示仕事を, 銅マトリクスのみ使用した再生 器を搭載した冷凍機の図示仕事で割つた值を用いている.

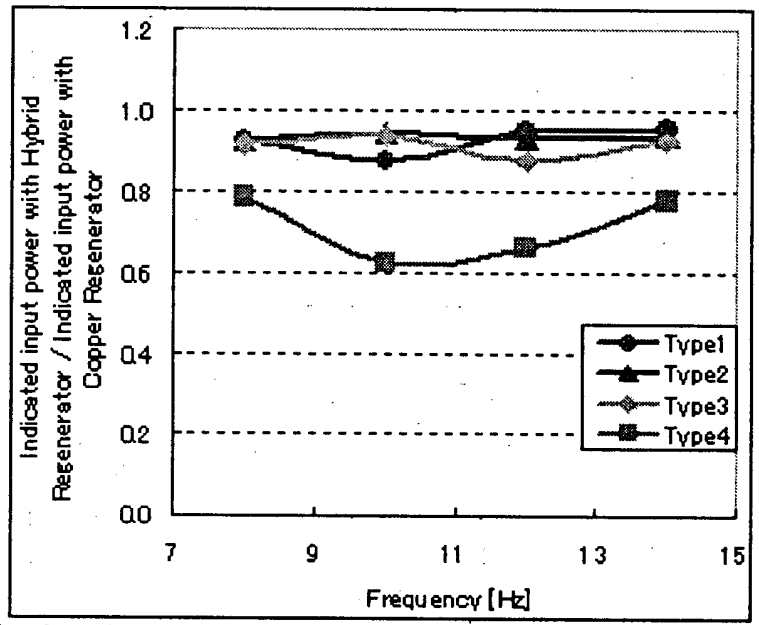

Fig. 8 Indicated input power with Hybrid Regenerator 
Fig. 8 よりどの混合方法のハイブリッドマトリクスを搭載 しても, 銅のみを使用した再生器を搭載した場合と比べて図 示仕事が低減されていることがわかる. Type1, Type2, Type3 は運転周波数による違いはあるが, 約 1 割程度の低減となう ている.しかし Type4 を用いた場合，銅のみを使用した再生 器を搭載した場合と比べ, 最大で図示入力を約 $40 \%$ 低減でき ることがわかる.

次に図示冷却量と運転周波数の関係を Fig. 6 に示す.これ もFig. 8 と同様に縦軸は実験から得られたハイブリッド再生 器を搭載した冷凍機の図示仕事を, 銅マトリクスのみ使用し た再生器を搭載した冷凍機の図示仕事で割った值を用いて いる.

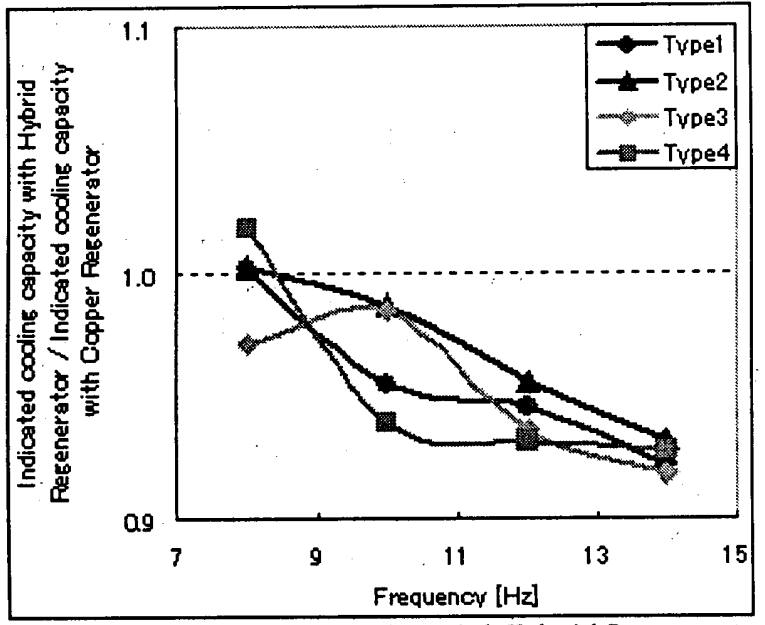

Fig. 9 Indicated Cool ing capacity wi th Hybrid Regenerator

Fig. 9 より図示冷却量はどの混合方法においても大きな差 はみられないことがわかる.つまり銅のみを使用した再生器 を搭載した冷凍機と混合率 $30 \%$ のイブリッド再生器を搭載 した冷凍機の図示冷却量は, その混合方法を変えても差はほ とんどないことがわかる. しかし全体的に運転周波数が増大 するに伴い, 図示冷却量は減少していることがわかる.これ はどの混合方法においてもほほ同じ減少量であることから， 運転周波数の増大によるナイロンマトリクスの再熱損失量 が, 銅マトリクスの再熱損失量よりも大きいことが要因であ ると考えられる.

最後に図示仕事と図示冷却量から得られる図示 COP を Fig. 10 に示す.これも Fig. 8,9 と同様に, 縦軸は実験から得 られたハイブリッド再生器を搭載した冷凍機の図示 COP を銅 マトリクスのみ使用した再生器を搭載した冷凍機の図示 COP で割った值を用いている.

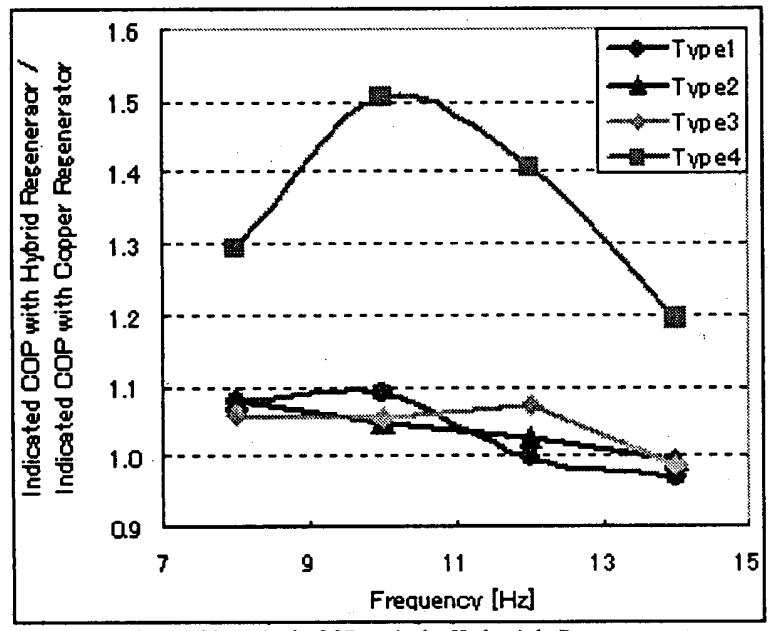

Fig. 10 Indicated COP with Hybrid Regenerator
Fig. 8, 9 より図示冷却量はどの混合方法にしても大きな差 はみられなかったため, 図示 COP は各混合方法における図示 仕事量の減少を大きく受けた結果となっている. 全体的に運 転周波数が増大すると図示 COP は減少する傾向にあることが わかる.Fig. 10 よりハイブリッド再生器は運転周波数が $10 \mathrm{~Hz}$ 程度の低回転域では銅のみを使用した再生器よりも高性能 であることがわかる.

\section{6. 結論}

ハイブリッドマトリクスの混合率 $30 \%$ におる銅マトリク スとナイロンマトリクスの混合方法の違いによるスターリ ング冷凍機の冷却特性について, P-V 解析を行なった結果, 次の知見を得た.

1. ナイロンマトリクスと銅マトリクスを交互に積層させ たハイブリッド再生器を搭載することにより, 銅マトリ クスのみを用いた再生器を搭載した場合と比較して図 示仕事を最大 4 割程度減少させることが可能である.

2. 銅マトリクスのみを用いた再生器を搭載した冷凍機と, 混合率 30\%のハイブリッドマトリクスを搭載した冷凍機 は，ほほ同一の図示冷却量を持つ．また混合方法の違い による図示冷却量の差はほとんどない。

3. 運転周波数が $10 \mathrm{~Hz}$ 程度の低回転域ではハイブリッドマ トリクスを用いることにより効率を向上させることが 可能である.

以上のことより, ハイブリッド再生器の有効性を示すこと ができた.

\section{7. 今後の展開}

本研究によりハイブリッドマトリクスを用いた再生器を 搭載したスターリング冷凍機の動作特性に関するデータを 得ることができた. しかし今回の解析は作動流体の封入圧力 が $300 \mathrm{kPa}$ の場合のみであり, 他の圧力での解析は行なって いない．加えて混合率が $30 \%$ 場合のみであり，更なる実験 データの蓄積を必要としているのは明らかである.

\section{8. 参考文献}

（1）山田敏男, 坂本守義; 村上和彦, 大高敏男, 井澤弘基, 「ナイロンマトリクス再生器を用いたスターリング冷 凍機に関する研究」日本機械学会 No. 97-41 第 1 回 スターリングシンポジウム講演論文集 (1997) P95-97

（2）関谷洋, 村上和彦, 大高敏男, 太田正廣, 「ナイロン一 銅混合メッシュ再生器の流動損失」日本機械学会 No.00-15 第4 回スターリングシンポジウム講演論文集 (2000) P169-172

（3）夏井博行, 太田正廣, 大高敏男, 「ハイブリッド再生器 を用いたスターリング冷凍機の冷却特性に関する研究」 日本機械学会 No.03-33 第7回スターリングシンポジ ウム講演論文集 (2003) P61-64

（4）山下䉷, 濱口和洋, 香川澄, 平田宏一, 百瀬豊「スター リングエンジンの理論と設計」, 山海堂 